
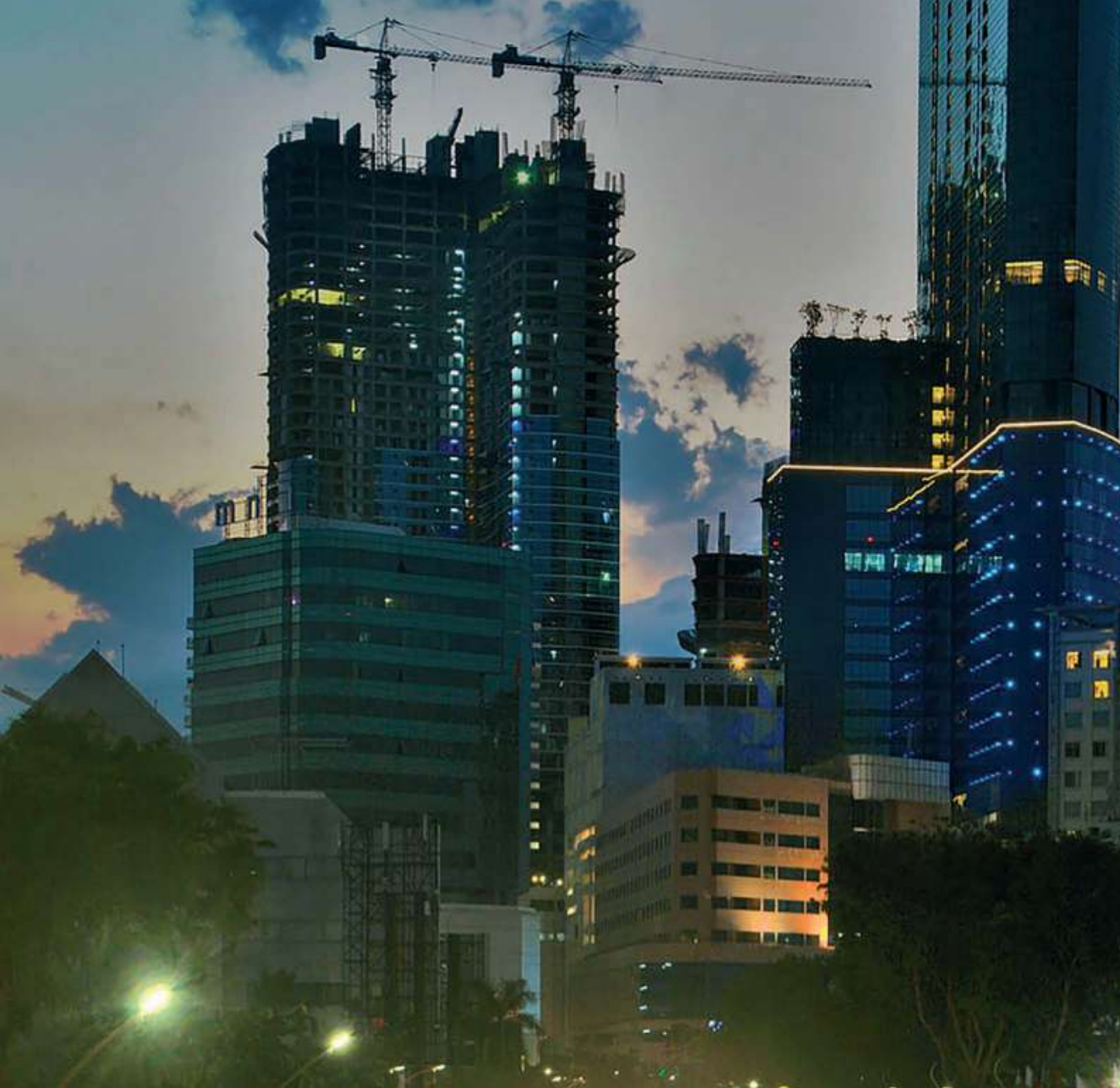

\section{Editors}

Badri Munir Sukoco

Rahmat Heru Setianto Nidya Ayu Arina Ade Gafar Abdullah Asep Bayu Nandiyanto Ratih Hurriyati

\section{Increasing Management Relevance \\ and}

\section{CPD \\ CERTIFIED

(ci. C) CRC Press

A BALKEMA BOOK 
PROCEEDINGS OF THE $2^{\text {ND }}$ GLOBAL CONFERENCE ON BUSINESS, MANAGEMENT AND ENTREPRENEURSHIP (GC-BME 2017), AUGUST 9, 2017, UNIVERSITAS AIRLANGGA, SURABAYA, INDONESIA

\section{Increasing Management Relevance and Competitiveness}

Editors

Badri Munir Sukoco, Rahmat Heru Setianto \& Nidya Ayu Arina Universitas Airlangga, Indonesia

Ade Gafar Abdullah, Asep Bayu Nandiyanto \& Ratih Hurriyati Universitas Pendidikan, Indonesia

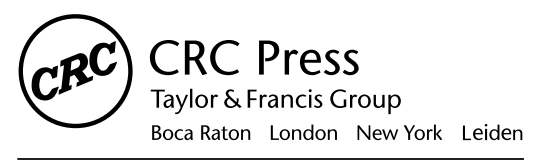

CRC Press is an imprint of the

Taylor \& Francis Group, an informa business

A BALKEMA BOOK 
CRC Press/Balkema is an imprint of the Taylor \& Francis Group, an informa business

(C) 2018 Taylor \& Francis Group, London, UK

Typeset by V Publishing Solutions Pvt Ltd., Chennai, India Printed and bound in Great Britain by CPI Group (UK) Ltd, Croydon, CR0 4YY

All rights reserved. No part of this publication or the information contained herein may be reproduced, stored in a retrieval system, or transmitted in any form or by any means, electronic, mechanical, by photocopying, recording or otherwise, without written prior permission from the publisher.

Although all care is taken to ensure integrity and the quality of this publication and the information herein, no responsibility is assumed by the publishers nor the author for any damage to the property or persons as a result of operation or use of this publication and/or the information contained herein.

Published by: CRC Press/Balkema

Schipholweg 107C, 2316 XC Leiden, The Netherlands

e-mail: Pub.NL@taylorandfrancis.com

www.crcpress.com - www.taylorandfrancis.com

ISBN: 978-0-8153-7455-8 (Hbk)

ISBN: 978-1-351-24189-2 (eBook) 


\section{Table of contents}

Preface $\quad$ xi

$\begin{array}{lc}\text { Acknowledgements } & \text { xiii }\end{array}$

$\begin{array}{ll}\text { Organizing committees } & \mathrm{XV}\end{array}$

Strategic management, entrepreneurship and contemporary issues

Governance of financial intangible success factors: An option in building business resilience and sustainability

P. Sugito

The influences of the alliance learning process and entrepreneurial orientation on the strategic alliance performance of Indonesian construction companies R. Handayani \& R. Dyah Kusumastuti

Assessing necessity and opportunity-based entrepreneurship: An analysis of demographic characteristics, propensity for new ventures and entrepreneurial motivation (a study of labor forces and entrepreneurs in Padang, Indonesia)

H. Rahman \& D. Lesmana

Critical assessment on zakat management: Zakat scorecard model

T. Widiastuti, S. Herianingrum \& I. Mawardi

Investigating entrepreneurial orientation impact on project performance in highly regulated industry: A case of renewable power industry in Indonesia

F.A. Firman, R.D. Kusumastuti, H.T. Kurniawan \& I.M. Ruky

How to survive in the modern era: Integrated local entrepreneurs, the traditional market and the modern store

P.P.D. Astuti, Y. Setyowati \& A.A.G.S. Utama

xi iii

XV

The influence of Islamic service quality toward bank customer loyalty and satisfaction of

BRISyariah Surabaya

M.Q. Fauzi, S. Herianingrum, T. Widiastuti \& R. P. Putra

Management accounting practices in micro enterprises in the Sleman Regency, Daerah

Istimewa Yogyakarta

A.C. Laksmi \& A.P. Putra

The power of finance: The dynamics of female entrepreneurs in fulfilling their financial needs

M.R. Rita, S. Wahyudi \& H. Muharam

Entrepreneurial orientation in a family business group: The role of the corporate center and its effect on business unit performance

O. Pendrian, K.A. Karnen, R. Rachmawati \& R.D. Kusumastuti

Developing entrepreneurship for the performing arts community through an art incubation model

J. Masunah \& R. Milyartini

Capability to contest on market performance

61

B. M. Sukoco \& R. R. Maulana 
The influence of the socio-economic status of parents toward entrepreneurial attitudes H. Mulyadi, M. Arief Ramdhany \& S. Sulastri

Analysis of the factors affecting the elected mode of transportation for workers using an analytical hierarchy process

E. Mahpudin \& H. Sulistiyo

71

75

Multidimensional approach for assessing service quality in the service industry

Y.D. Lestari

The influence of entrepreneurship orientation and management capability on performance of small and medium enterprises in Bogor

A. Setyo Pranowo, H. Hari Mulyadi, Z. Musannip Efendi Siregar \&

Y. Hendayana

The influence of family factors on expatriate performance

N. Kartika

Is firm size an important determinant for firms in establishing political connections?

N.N. Amorita, D. Agustia \& I. Harymawan

Integration of corporate social responsibility and resource based theory to create

and capture value

N. Nandang \& H. Mulyadi

Organizational behavior, leadership and human resources management

Superior performance model of human resources

T. Yuniarsih, Disman \& M.D. Sugiharto

The impact of fiscal decentralization on economic growth and manpower absorbed at districts/cities in South Kalimantan Province

Muzdalifah \& R. Purwono

Work-family conflict and satisfactions: A job demand-resources model perspective

J. Sulistiawan

Building employee engagement through transformational leadership, psychological empowerment and affective commitment

P. Yulianti \& N. Hamidah

The impact of transformational leadership, learning organization and job autonomy on creative self-efficacy

I. B. G. A. Permana \& W. Astiti

Enhancing commitment to organizational change initiative and performance outcomes N.A. Arina \& P. Yulianti

The influence of Perception of Usefulness (PoU) and Perceived Ease of Use (PEU) on the perception of information system performance

F. Sayekti \& L.E. Wijayanti

Knowledge sharing benefits: The contingency effects of environmental contexts

A. Qomariyah

The antecedents of entrepreneurial intentions in students of Airlangga university

(A study of student participants in WEBS in the faculty of economics and business)

P. Yulianti \& I. G.N.W.H. Saputra

Effect of proactive personality and Organizational Support for Career Development (OSCD) on career satisfaction and job performance

V. Octia \& D. Ratmawati

The effects of transformational and transactional leadership on work performance of middle-level leaders with organizational commitment as mediator: A study of state-owned company, Pelabuhan Indonesia III Inc.

A. Eliyana, S. Maarif \& R.J. Sunarsono 
Transformational leadership style, team performance and team job satisfaction:

Mediation by levels of cognitive trust and collective efficacy

P. Yulianti \& R. Sanjaya

The impact of self-efficacy and perceived organizational support on operational managers' readiness to change

H. Prima \& A. Eliyana

\section{Marketing management}

Factors affecting customer retention in a priority banking program

I.R. Aliyah, S. Soebandhi \& A. Baktiono

The impact of messages assertiveness on compliance with perceived importance as a moderation variable on the anti-cigarette campaign in Surabaya

Kristiningsih, R.S. Wuryaningrum \& A. Trimarjono

Demographic variables and environmentally friendly behavior in a developing country

T. Handriana

Antecedents and consequences of ongoing search information

D. T. Firmansyah \& D. Mardhiyah

Role of negative brand name perception and religiosity on brand attitude

S. Gunawan \& R.T. Ratnasari

The effects of good/bad news on consumer responses toward higher education

G.C. Premananto \& M.H. Hanafiah

Examining leadership style and advertising evaluation on employees'

customer focus

R.A. Aisyah \& N.A. Arina

The effect of airline sale promotion types on consumers' attitudes toward brand and purchase intentions

M. Kurniawati

The influence of celebgrams, e-WOM, and pictures on impulse buying

Hartini, Sri \& Uswatun

Value propositions of supermarkets

R. Rinawati

Empirical study of perceived quality information and perceived information security impact on online purchasing in Indonesia

L. Lisnawati, L.A. Wibowo \& P. Andi

Measuring religiosity and its effects on attitude and intention to wear a hijab:

Revalidating the scale

H.A. Wibowo \& M.R. Masitoh

\section{Management and economics education}

Communication skills of accountants and managers in Indonesia

Y.L. Rudianto \& A.R. Sridadi

Factors knowledge management and the work motivation of lecturers

Rino

The role of talent management in student performance in higher education

D. Purwaningsih

Strategy to build universities

P. Dewi Dirgantari, B. Widjajanta \& L. Lisnawati

Factors affecting the improvement of students' Grade Point Average (GPA)

A.B. Santoso, E.C.M. Simatupang \& R.H. Sofyandi 
Innovation, operations and supply chain management

Analysis of the small segment credit business process at Bank ABC Indonesia

A.C. Saifullah \& R.D. Kusumastuti

The identification of defects in rubber slipper production using the six sigma method

T.A. Auliandri \& M.A. Setiani

The design of service quality improvement in a library by using LibQUAL model and fishbone diagram

F. Wurjaningrum \& A. Kurniawan

The strategic role of Indonesia in Global Value Chains (GVC)

M.A. Esquivias, D. W. Sari \& R.D. Handoyo

N. Anridho

Efficiency and total-factor productivity in the manufacturing industry in

33 provinces of Indonesia

Muryani

Academic excellence and total quality supply chain management in higher education

I. Usman \& Windijarto

Financial management and accounting

The influence of usage accounting information on small medium enterprise's perception

S. Mintarti, D. M. Sari \& T. Fitriastuti

Determinants of banks' net interest margin in five South East Asian countries

M. Gitanadya \& R. Setiawan

The effect of monetary policy and macroeconomic variables on foreign portfolio investment in Indonesia

N.F. Anne \& R. Purwono

Internal factors, external factors, and bank liquidity in Indonesia

I.M. Sudana \& A.F. Akbar

The obstacles in developing Indonesia's sovereign sukuk

N. Laila, F.F. Hasib \& M. Anshori

The effect of trading volume changes on JKSE's market return

M. Madyan, S. Hasan \& D.F. Putri

The influence of the profitability indicator, capital and performing loans on the liquidity of the bank in the Indonesian stock exchange

O.V.B. Nainggolan

Corporate governance performance evaluation of banks operating in Indonesia

F. Budhijono

What drives finance pattern debt companies to pay dividends in Indonesia?

L. Gestanti \& G. Memarista

Diversification, firm value and government ownership

S. A. Usman \& C. Sulistyowati

Do operating costs, investment returns and claims have an effect on contributions?

D.F. Septiarini

S.R. Arifin \& Wisudanto

Different ways to solve the liquidity problem of Indonesian Islamic microfinance

I. Mawardi \& T. Widiastuti 
Determinant of banks stock risk in Indonesia

Degree of internationalization and firm financial performance

F. Ismiyanti

Cost efficiency of Indonesian banks over different groups of capital

M. Anwar

Analysis of investor preference in investing on initial public offering M. Sari

Female directors, nationality diversity, and firm performance: Evidence from the mining industry in Indonesia

Y.S. Putri, M. Nasih \& I. Harymawan

Sharia governance framework in Islamic banking and financial institutions in Indonesia:

A proposed structure

M.I.S. Mihajat

Mediating role of Investment Opportunity Set (IOS) on diversification-corporate value relationship: Empirical study of manufacturing companies in the IDX, 2013-2015

D. W.I. Hartono, B. Tjahjadi, N. Soewarno \& Y. Permatasari

Underpricing, operating performance, long-term market performance, and the probability of conducting seasoned equity offerings of IPO in Indonesian capital market

N. Sasikirono, Djumahir \& A. Djazuli

The effects of firm size, good corporate governance, and business risk towards financial performance with corporate social responsibility as the moderating variable N. Soewarno, E.S. Wulandari \& B. Tjahjadi

The effect of good corporate governance on financial performance with capital structure and earnings management as mediating variables

N. Soewarno, B. Tjahjadi \& B.D.P. Utomo

The impact of IFRS adoption on earnings management in the banking and mining sectors

H. Musvosvi

Managerial ownership and corporate diversification in the family and non-family businesses T. Perdana \& N. Fitdiarini

CEO gender, corporate finance decisions, and performance

R. H. Setianto \& J. Mahbubi

Empirical testing of the accuracy of various theory models to measure the value of the firm N.D. Kusumaningrum \& I. M. Narsa

Determinant variables of the performance rating of banks operating in Indonesia Sugiarto

Fraud prevention analysis in the financial management of local government

A. A. Nugroho \& Y.N. Supriadi

The effect of leverage and profitability on stock return: A study on the mining sector companies listed on the Indonesia stock exchange for the period 2011-2015

Y. Hendayana, H. Hari Mulyadi, Z. Musannip Efendi Siregar \&

A. Setyo Pranowo

Asymmetric information at first seasoned equity offering in the Indonesian capital market

H. Meidiaswati, Basuki \& A. Irwanto

Efficiency analysis of economic empowerment program in Surabaya National Amil Zakat Institution using Data Envelopment Analysis method (DEA)

F. Ramadhani \& E.F. Cahyono 


\title{
Determinant of banks stock risk in Indonesia
}

\author{
R. Setiawan \& R. Anggraeni \\ Universitas Airlangga, Surabaya, Indonesia
}

\begin{abstract}
The purpose of this study is to examine the determinant of bank's stock risks on the Indonesian Stock Exchange. This study uses a multiple linear regression analysis model, and the data was obtained from the bank's financial statements published during the 2006-2015 period. The dependent variable in this study is the bank's stock risk that is proxied by the standard deviation of the daily bank's stock risk. The independent variables in this study are the book value Equity to Total Asset (EQTA), Non-Performing Loan (NPL), Liquid Asset to Total Asset (LIQATA), and Standard Deviation of ROA (SDROA). The results showed that NPL and SDROA have a positive influence on bank stock risk, while EQTA and LIQATA have a negative influence on bank stock risk.
\end{abstract}

Keywords: bank's stock risk, book value Equity to Total Asset (EQTA), Non-Performing Loan (NPL), Liquid Asset to Total Asset (LIQATA), Standard Deviation of ROA (SDROA)

\section{INTRODUCTION}

The existence of the banking sector in the economy of a country has an important role, even in the daily life of the community mostly involving services from the banking sector. This is because the banking sector has the primary function as a financial intermediary between excessive economic units and underfunded economic units. Through a bank can be collected funds from the community in various forms of the subsequent deposits of funds that have been collected by the bank and channeled back in the form of credit to the business sector or other parties in need.

The globalization of the economy has made progress in the banking system, but on the other hand, it also poses various risks due to the world economy. In addition, the increasing complexity of the business activities of banks has the potential to lead to higher risks being faced. This increased risk needs to be followed by an increase in the capital required by banks to bear the likelihood of losses. Hanafi (2009) defined risk as a possible result of deviation other than what is expected.

All banking companies must be prepared against all kinds of risks faced. If the risk is not properly managed, the bank may fail and eventually end up in bankrupt. Risk in the business context does not always represent something bad. Risk can be an opportunity for those who can manage it well. Banking wherever it is located will not be separated from the risks arising from all activities undertaken. There is no other way for banks to avoid the risks in addition to implementing a strategy of reliable management in controlling the risks that it faces itself.

Banking risk management is very important for banks. It concerns the success and failure of the banks in running operations. If banks can manage the risk well, it is expected that the banks will increase their returns. However, if the bank is not able to handle the risks properly, then the probability of bankruptcy will also increase. The essence of the implementation of risk management is the risk management methodology used so that the bank's business activities can be controlled within acceptable limits and benefit the banks.

The banking industry is one of the industries selected by investors in which to invest their capital. The existence of a more predictable level of financial globalization poses new and complex risks that investors must confront. Generally, investments made by investors in the capital market are to earn returns, but investors also need to look at the risks that exist in the securities because of the uncertainty in the investment. The risk due to the uncertainty of stock prices or the returns obtained by investors in the capital market is called the risk of shares. According to Agusman et al. (2008), stock risk can be reflected in the fluctuation of stock prices in the capital market.

According to Sudana (2011), there are three types of investor behavior against risk, namely risk seeker, indifferent to risk, and risk averter. For investors who are risk seekers, a big risk will be preferred because of the amount of return that will be obtained. But there are also investors who are risk averters that try to minimize the risk but 
still expect a high return. Thus, risk is one of the parameters that is important for investors to use to determine the return and to identify the factors that affect risk. Agusman et al. (2008) stated that there are several types of financial ratios related to stock risk, among others, book value equity to total asset, non-performing loan, liquid asset to total asset, and standard deviation of ROA.

The four financial ratios related to stock risk are indicators of bank performance. By using the bank's performance indicators, it is expected that investors will be able to respond to whether the banks they are going to buy in to are worthy to make investments in line with the risk of the stocks that will be generated later on. Book value equity to total assets is the proportion of capital to the total assets owned by banks. If the bank has its own capital with an amount greater than the debt, it is expected to create a risk of bank stocks in the small capital market. A non-performing loan is how much problem loans are owned by the bank. If a bank has a large portion of bad loans, the losses are to be borne by the bank. This causes the risk towards the bank shares in the capital market. High liquid asset to total assets is how much of the bank's liquid assets can be used to maintain liquidity. If the bank can manage their assets until it can avoid a liquidity risk, then the bank is considered to be a healthy bank and this causes the risk of shares in the capital market to be low. The standard deviation of ROA illustrates the uncertainty of the profitability obtained by the bank. Jika's high profitability is uncertain, considering that the bank is not healthy and this causes the risk of bank shares in the capital market to also be high. Below is the risk of banking stock data from 20062015. It did not show any significant increases or decreases in trends. Below is the data of the banking stock risk from 2006-2015 as measured using the standard deviation of the daily stock returns.

Based on the above data, it can be seen that the risk level of banking stock is unstable. From this phenomenon, the researcher wanted to research about the effect of stock risk instability with five financial ratios, namely book value equity to total

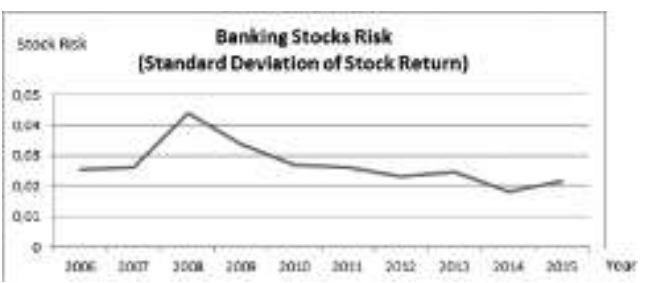

Figure 1. Risk data of banking stocks period 2006-2015. asset, non-performing loan, liquid asset to total asset, and the standard deviation of ROA. Aside from the phenomenon itself, the research was on the influence of banking risk with the five financial ratios mentioned. This is rarely done in Indonesia, so the researcher wanted to examine the effect of bank stock risk on book value equity to total asset, non performing loan, liquid asset to total asset, and the standard deviation of ROA. Based on the description of the above background, the formulation of the research problem is as follows:

1. Does book value equity to total asset negatively affect the risk of bank stock?

2. Does a non-performing loan positively affect the risk of bank stock?

3. Does liquid asset to total asset negatively affect the risk of bank stock?

4. Does the standard deviation of ROA positively affect the risk of bank stock?

\section{THEORETICAL BASIS}

\subsection{Understanding bank}

According to Law no. 10/1998 about banking, a bank is a business entity that collects funds from the public in the form of savings and distributes it to the community in the form of credit and/or in other forms in order to improve the standard of living of the community. The purpose of banking is explained in article 3 of Law no. 10/1998; to support the implementation of national developments in order to improve equity, economic growth, and national stability towards improving the welfare of the people.

\subsection{Bank stock risk}

Risk is the possibility of the results obtained that deviate from the expected (Hanafi, 2009). Meanwhile, according to Sudana (2011), risk is defined as the variability of the actual investment return on the expected investment results. So it can be concluded that the risk of the stocks is a possibility. The results obtained deviate from the expected, which are the results of the stock investments. Referring to Agusman et al (2008), the risk of bank stock in this study is measured using the standard deviation of daily stock return. The standard deviation indicates how far the probability of the value obtained deviates from the expected value. The greater the standard deviation value, the greater the probability that the true value deviates from the expected meaning. Therefore, the higher the risk. Referring to Agusman et al (2008) and Ehrhardt and Brigham (2001), stock risk is measured using the standard deviation of daily stock returns. 


\subsection{Book value Equity to Total Asset (EQTA)}

The ratio of book value equity to total assets is a ratio that shows how much of the bank's equity portion is out of the total assets owned.

\subsection{Non-Performing Loans (NPLs)}

The non-performing loan ratio is the ratio between the total non-performing loans and the total loans granted to debtors (Rivai et al., 2012). The smaller the ratio, the smaller the risk of the possibility of uncollectible loans compared to the total amount of loans granted, which leads to bank profits (Rivai et al 2012). Banks are said to have a high ratio of non-performing loans if the number of credit problems are relatively large.

\subsection{Liquid Asset to Total Asset (LIQATA)}

The ratio of liquid assets to total assets is a comparison of a bank's liquid assets to their total assets (Agusman et al, 2008). Liquidity is one of the indicators used to measure the company's ability to meet its short-term liabilities. According to Rivai et al (2012), liquidity is the ability of the bank's management in providing sufficient funds to meet its obligations at any time. Management in terms of liquidity is very necessary, because if the bank lacks liquidity then it can disrupt not only the bank, but also the banking system as a whole.

\subsection{Standard Deviation of Return on Asset (SDROA)}

The standard deviation ratio of ROA is a risk of profitability generated by banks (Agusman, et al., 2008). Risk itself has the meaning of uncertainty, and ROA is the ability of banks in managing their assets to generate profit. It can be concluded that the standard deviation of ROA is the uncertainty to do with the earnings obtained by banks.

\subsection{The effect of book value equity to total asset on bank stock risk}

The ratio of book value equity to total asset negatively affects the risks to do with bank stock. This indicates that the higher the book value equity to the total asset ratio, the lower the risk of the stocks to be faced by the bank (Agusman, et al., 2008). This ratio is negatively related to the risk of bank shares because the percentage of the bank's operational activity is more funded by the bank's own equity than debt, where the debt itself will cause a fixed burden of interest (Pettway, 1976 in Salked, 2011). If the bank's debt is less than the equity, the interest on the bank will not be too large. Equity absorbs the possibility of losses and provides the basis for maintaining customer confidence. The greater the equity, the greater the financial resources that can be used for business development purposes and to anticipate potential losses, as a result of lending.

Banks with a large equity will face lower bankruptcy risks and may earn lower funding costs. People trust banks that have greater equity than debt, because they feel that the funds held in the bank will be safe with the equity of banks to protect their funds in the event of a loss. Investors will also trust banks that have greater equity than debt because investors believe that banks with greater equity can guarantee the value of their investments, at least with a value that remains stable. The risk of stocks on investments is subsequently low. The maximum bank equity will be able to improve the bank's management capabilities in identifying, measuring, controlling and controlling risks arising later. The higher the book value equity compared to the total asset ratio, the lower the risks to do with bank stock.

H1: Book value equity to total assets negatively affects the risk of bank stock.

\subsection{The effect of non-performing loans on bank stock risk}

The ratio of non-performing loans positively affects the risk of bank stock. This means that the higher the ratio of non-performing loan-giving banks, the higher the risk of stocks faced by the banks (Mamoghli, 2009). The non-performing loan ratio is the percentage of the number of nonperforming loans faced by the bank. The high rate of non-performing loan as indicated by the higher ratio of non-performing loan indicates the low ability of the debtors to pay back all of their loan or credit provided by the bank. This can increase the cost (opportunity cost) resulting in potential losses in the banks. The high ratio of non-performing loans has been proven to cause the banks to suffer losses due to that magnitude of change. Banks should be careful in channeling credit in order to avoid high non-performing loans, or to deal with it in a more selective way when it comes to channeling credit to the community. Investors consider that banks with high non-performing loans are considered to be unhealthy and risky banks. The effect of the high non-performing loan ratio is that the bank will experience more credit risk. If the bank is exposed to credit risk, this will lead to the disruption of bank liquidity because it has to bear the losses due to the risk of default from the debtor. If bank liquidity gets disturbed and also has credit risk involved, investors will assume that the bank is unhealthy and investors will not trust to invest its shares in the bank. When no investors 
invests in the bank, the share price of the bank will fall, and the risk of the bank's shares will be high. Thus, the higher the ratio of non-performing loans, the higher the risk of bank stock.

$\mathrm{H} 2$ : Non-performing loans positively affect the risk of bank stock.

\subsection{The effect of liquid asset to total asset on bank stock risk}

The ratio of liquid assets to total assets has a negative effect on bank stock risk. This means that the higher the bank's liquid assets, the lower the risk of stocks faced by the bank. If this ratio shows a high number, it indicates that the bank has a large liquid asset, thus has a relatively small liquidity risk. Banks with large liquid assets are expected to buffer unexpected losses in the short term, as the amount of available liquid assets is greater and avoids the liquidity risk. If the public wants to withdraw their funds by a large amount, the bank can serve them immediately. Investors consider banks with liquid assets of a considerable value to be rated as sound banks because they can avoid the liquidity risk. Investors will invest in the bank, so the stock price of the bank will rise, and the risk of its shares will fall. Thus, the higher the liquid asset to total asset, the lower the risk faced by the bank.

H3: Liquid asset to total assets negatively affects the risk of bank stock.

\subsection{The effect of standard deviation of ROA ratio on bank stock risk}

The standard deviation of ROA ratio positively affects the risk of bank stock. This means that the higher the standard deviation of the bank's ROA, the higher the risk of stocks faced by the bank. The high ROA variability value reflects the instability of bank management in managing its assets to generate profit, so that the profit generated also fluctuates. Banks that have not been able to manage their assets well cause operational activities to be undertaken by that banks that is not good. This causes the profit generated by the bank to fluctuate. Fluctuating earnings leads to uncertainty faced by banks. For investors, profit is one of the main elements of bank health information. When a bank's earnings are experiencing instability, this indicates that the performance of the bank is not maximized because it cannot maintain stability or even increase its profit. This phenomenon becomes a bad signal for investors, because the banks are considered to be unhealthy and this will be reflected in the stock price of the banks in the capital market. The resulting risk of capital faced by the banks will be high. This causes the higher risk of stock to be faced by the bank. Thus, the higher the standard deviation of ROA, the higher risk of shares faced by the bank.

H4: Standard deviation of ROA positively affects the risk of bank stock.

\section{RESEARCH METHOD}

\subsection{Sample}

The sample in this study was a banking company listed on the Indonesian Stock Exchange operating in the period 2006-2015. The sample firm has a financial report with complete data-related variables to be used. Sharia banks have not been included in the samples because sharia companies do not distribute community funds in the form of interest-based credit but in the form of financing based on the results so as not to face credit risks.

\subsection{Operational definition and variable measurement}

\subsubsection{Dependent variable}

Bank Stock Risk (RISK)

$\operatorname{RISK}_{\mathrm{i}, \mathrm{t}}=\sqrt{\frac{\sum_{\mathrm{d}=1}^{\mathrm{n}}\left(\overline{\mathrm{r}}_{\mathrm{i}, \mathrm{d}}-\overline{\mathrm{r}}_{\text {avg }, \mathrm{i}, \mathrm{d}}\right)^{2}}{\mathrm{n}-1}}$

$\overline{\mathrm{r}}_{\mathrm{i}, \mathrm{d}}=$ daily stock return bank $\mathrm{i}$ at day $\mathrm{t}$;

$\bar{r}_{\text {avg,i,d }}=$ average daily stock return bank $i$ at day $\mathrm{t}$.

\subsubsection{Independent variable}

1. Book value Equity to Total Asset (EQTA)

EQTA $_{\mathrm{i}, \mathrm{t}-1}=\frac{\text { Total Equity }_{\mathrm{i}, \mathrm{t}-1}}{\text { Total Asset }_{\mathrm{i}, \mathrm{t}-1}}$

2. Non Performing Loan (NPL)

$\mathrm{NPL}_{\mathrm{i}, \mathrm{t}-1}=\frac{\text { Non Performing } \operatorname{Loan}_{\mathrm{i}, \mathrm{t}-1}}{\text { Total Loan }_{\mathrm{i}, \mathrm{t}-1}}$

3. Liquid Asset to Total Asset (LIQATA)

LIQATA $_{i, t-1}=\frac{\text { Liquid Asset }_{i, t-1}}{\text { Total Asset }_{i, t-1}}$

4. Standard Deviation of Return on Asset (SDROA)

$\operatorname{SDROA}_{\mathrm{i}, t-1}=\sqrt{\frac{\sum_{\mathrm{i}=1}^{\mathrm{n}}\left(\overline{\mathrm{ROA}_{1, \mathrm{t}-1}}-\overline{\mathrm{ROA}_{\text {avg, }, 1, \mathrm{t} 1}}\right)^{2}}{\mathrm{n}-1}}$ 


\subsection{Data analysis method}

The model of analysis in this research is

$$
\begin{aligned}
\text { RISK }_{\mathrm{i}, \mathrm{t}}= & \alpha+\beta_{1} \text { EQTA }_{\mathrm{i}, \mathrm{t}-1}+\beta_{2} \text { NPL }_{\mathrm{i}, \mathrm{t}-1} \\
& +\beta_{3} \text { LIQATA }_{\mathrm{i}, \mathrm{t}-1}+\beta_{4} \text { SDROA }_{\mathrm{i}, \mathrm{t}-1}+\varepsilon_{\mathrm{i}, \mathrm{t}-1}
\end{aligned}
$$

where, RISK $_{\text {it }}$ is bank stock risk bank i year t, EQTA $_{i, t-1}$ is book value equity to total asset bank i year $t-1, N L_{i, t-1}$ is non-performing loan bank $i$ year $\mathrm{t}-1$, LIQATA LI,t-1 $_{1}$ is liquid asset to total asset bank i year $\mathrm{t}-1, \mathrm{SDROA}_{\mathrm{i}, \mathrm{t}-1}$ is standard deviation of ROA bank i year $\mathrm{t}-1$.

\section{RESULT AND DISCUSSION}

\subsection{Results of the research analysis}

Table 1. Data description.

\begin{tabular}{lllllll}
\hline & & & & & \multicolumn{2}{l}{$\begin{array}{l}\text { Std. } \\
\text { deviation }\end{array}$} \\
\hline RISK & 113 & 0,0111 & 0,0482 & 0,0244 & 0,0070 \\
EQTA & 113 & 0,0529 & 0,2601 & 0,1087 & 0,0314 \\
NPL & 113 & 0,0000 & 0,1050 & 0,0283 & 0,0165 \\
LIQATA & 113 & 0,0536 & 0,1434 & 0,0924 & 0,0190 \\
SDROA & 113 & 0,0002 & 0,0138 & 0,0038 & 0,0028 \\
Valid N & 113 & & & & \\
\hline
\end{tabular}

Source: Data processed.

Table 2. Regression analysis results.

\begin{tabular}{lcll}
\hline Variable & Coefficient & Sig. t & Result \\
\hline Konstanta & 0,031 & 0,000 & \\
EQTA & $-0,044$ & $0,030^{* *}$ & Significant \\
NPL & 0,093 & $0,026^{* *}$ & Significant \\
LIQATA & $-0,069$ & $0,039^{* *}$ & Significant \\
SDROA & 0,437 & $0,064^{*}$ & Significant \\
\hline $\mathrm{R}^{2}$ & 0,207 & &
\end{tabular}

Dependent Variable: RISK.

$* *=$ Significant at $5 \%, *=$ Significant at $10 \%$.

\subsection{The effect of book value equity to total asset on bank stock risk}

Book value Equity to Total Asset has a significant negative effect on bank stock risk. This means that the higher the book value equity to the total asset ratio, the lower the risk of stock to be faced by the bank (Agusman et al, 2008). This ratio is negatively related to the risk of bank stocks because the percentage of the bank's operational activities is funded by the bank's own equity rather than debt, whereas the debt itself will create a fixed burden of interest (Pettway, 1976). If the bank's debt is less than the equity, the interest on the bank will not be too large. Equity absorbs the possibility of losses and provides the basis for maintaining customer confidence. The greater the equity, the greater the financial resources that can be used for business development purposes and to anticipate potential losses, as a result of lending. Banks with large equity will face lower bankruptcy risks and may earn lower funding costs. People trust the banks that have greater equity than debt, because they feel that the funds held in the bank will be safe with the equity of the banks in place to protect their funds in the event of a loss. Investors will also trust banks that have greater equity than debt because investors believe that banks with greater equity can guarantee the value of their investments, at least with a value that remains stable, so the risk of stocks on investments is low. The maximum bank equity will be able to improve the bank's management capability in identifying, measuring, controlling and controlling risks arising later. The higher the book value equity to total asset ratio, the lower the risk of bank stock.

\subsection{The effect of non-performing loans on bank stock risk}

The ratio of non-performing loans has a significant positive effect on bank stock risk. The higher the ratio of non-performing loans in banks, the higher the risk of stocks faced by the aforementioned banks (Mamoghli, 2009). The non-performing loan ratio is the percentage of the number of nonperforming loans faced by banks. The high rate of non-performing loans indicated by the high ratio of non-performing loans indicates the low ability of debtors to pay for all of the loans provided by the bank. This can increase the cost at the bank. The high ratio of non-performing loans has been proven to cause the bank to suffer losses that amount to change. Banks should be careful in channeling credit in order to avoid high non-performing loans. Investors consider that banks with high non-performing loans are considered to be unhealthy and risky banks. The effect of the high non-performing loan ratio is that the bank will experience more credit risk. If the bank is exposed to credit risk, this will lead to the disruption of the bank's liquidity because it has to bear the loss from the risk of the default of the debtor. If the bank liquidity gets disturbed and also involves credit risk, investors will assume that the bank is unhealthy and investors will not trust to invest their shares in the bank. When no investor invests in the bank, the share price of the bank will fall, and the risk of the bank's shares will be high. Thus the higher the ratio of non-performing loans, the higher the risk of bank stock. 


\subsection{The effect of liquid asset to total asset on bank stock risk}

The ratio of liquid assets to total assets has a significant negative effect on bank stock risk. This means that the higher the bank's liquid assets, the lower the risk of stocks faced by the bank. If this ratio shows a high number, it indicates that the bank has a large liquid asset, and thus has a relatively small liquidity risk. Banks with large liquid assets are expected to buffer unexpected losses in the short term, as the amount of available liquid assets is greater. If the public wants to withdraw their funds in relation to a large amount, the bank can serve them immediately. Investors consider banks with liquid assets to be of considerable value to be rated as sound banks because they can avoid the liquidity risk. Investors will invest in the bank, so the stock price of the bank will rise, and the risk of its shares will fall. Thus, the higher the liquid asset to total asset ratio, the lower the risk faced by the bank.

\subsection{The effect of standard deviation of ROA ratio on bank stock risk}

The standard deviation ratio of ROA has a significant positive effect on bank stock risk. This means that the high standard deviation of ROA is owned by the bank, and affects the high risk of bank stocks. The high ROA variability value reflects the instability of the bank's management in managing its assets to generate profit, so that the profit generated also fluctuates. Banks that have not been able to manage their assets well cause the operational activities undertaken by the banks to not be so good. This causes the profit generated by the bank to fluctuate. Fluctuating earnings leads to uncertainty. For investors, profit is one of the main elements of bank health information that are looked at prior to making a decision. When a bank's earnings are experiencing instability, this indicates that the performance of the bank is not maximized because it can't maintain stability or even increase its profit. This phenomenon becomes a bad signal for investors, because the banks are considered to be unhealthy and this will be reflected in the stock price of the banks in the capital market. The risk of capital faced by banks will be high. This causes the higher risk of stock to be faced by the bank. Thus, the higher the standard deviation of ROA, the higher the risk of shares faced by the bank.

\section{CONCLUSION}

Based on the research conducted on 113 observations of bank research registered on Indonesian Exchange in 2006-2015, the following conclusions have been generated:
1. Book value equity to total asset and liquid asset to total assets has a significant negative effect on bank stock risk. This shows that the higher the ratio of book value equity to total asset and liquid assets to total assets, the lower the risk of bank stock.

2. Non-performing loans and standard deviation of ROA have a significant positive effect on bank stock risk. This shows that the higher the non performing loan ratio and standard deviation of ROA, the higher the risk of bank stock.

\section{REFERENCES}

Abdullah, A. M. A. 2003. The Relationship Between Commercial Banks Performance and Risk Measures. A Case of Saudi Arabia Stock Market. Journal of KingFaisal University 4 (2): 1424.

Agusman, A. et al. 2007. Accounting and Capital Market Measures of Risk: Evidence from Asian Banks during 1998-2003. Journal of Banking \& Finance 32 (2008): 480-488.

Al-Jarrah, I. M. 2012. Evaluating the Riskiness of the Banking Sector of Jordan. European Journal of Economics, Finance and Administrative Sciences 48 (2012).

Bank Indonesia. 1998. Undang-undang No. 10 Tahun 1998. - 2015. Peraturan Bank Indonesia No. 17/11/PBI/2005.

Brigham, E. F. \& Houston, J. F. 1998. Fundamentals of Financial Management. Eight Edition. New York: The Dryden Press. Harcourt Brace College Publishers.

Darmawi, H. 2011. Manajemen Perbankan. Jakarta: Bumi Aksara.

Dendawijaya, Lukman. 2005. Manajemen Perbankan. Edisi Kedua. Jakarta: Ghalia Indonesia.

Dhouibi, R. \& Mamoghli, C. 2009. Accounting and Capital Market Measures of Risk: Evidence from an emerging market. Banks and Bank Systems 4 (4).

Elyasiani, E. \& Mansur, I. 1998. Sensitivity of the bank stock returns distribution to changes in the level and volatility of interest rate: A GARCH-M model. Journal of Banking and Finance 22: 535-563.

Gozhali, I. 2007. SPSS. Analisis Multivariat dengan Program SPSS. Semarang: Badan Penerbit Universitas Diponegoro.

Hanafi, M. M. 2010. Manajemen Risiko. Edisi Kedua. Yogyakarta: UPP STIM YKPN.

Hartono, J. 2014. Teori Portofolio dan Analisis Investasi. Edisi ke 9. Yogyakarta: BPFE-Yogyakarta.

Jarvela, M., et al. 2009. The Relationship Between Market and Accounting Determined Risk Measures: Reviewing and Updating the Beaver, Kettler, Scholes (1970) Study. College Teaching Methods \& Style Journal, Special edition 2009.

Rivai, V., Basir, S., Sudarto, S., \& Veithzal, A. P. 2013. Commercial Bank Management. Jakarta: Raja Grafindo Persada.

Salked, M. 2011. Determinants of Bank's Total Risk: Accounting Ratios and Macroeconomics Indicators. Honors Projects 24.

Santoso, S. 2002. Aplikasi SPSS pada Statistik Multivariat. Jakarta: Elex Media Komputindo.

Sudana, I Made. 2011. Manajemen Keuangan: Teori dan Praktik. Surabaya: Erlangga. 